\title{
The NeEd For a Unified Patent Court
}

\section{Accepted \\ 2. 6.2020 \\ Revised \\ 5. 6. 2020 \\ Published \\ 22. 6. 2020}

UDC

347.771:347.9:061.1EU

Keywords

Unified

patent

court,

European

unitary

patent,

European

patent

convention,

patent

itigation,

European

patent

system.

\section{EUGÉNIO LUCAS}

Instituto Politécnico de Leiria, Instituto Jurídico Portucalense, Leiria, Portugal, e-mail: eugenio.lucas@ipleiria.pt

CORRESPONDING AUTHOR

eugenio.lucas@ipleiria.pt

Abstract This article discusses the need of a Unified Patent Court, as a major contribution for the implementation of the European unitary patent. It begins by outlining the evolution of European patent rights and identifying the problems of the current system. Implementing a Unified Patent Court will be defended as a solution for one of the most important problems of the European patent: the lack of a central mechanism of jurisdictional control. The current model of jurisdictional control gives rise to a situation of great legal uncertainty and has diminished the value of European Union patent rights. We will analyse the virtues and disadvantages of the new European Unitary Patent resulting from the adoption of Regulations (EU) 1257/2012 and 1260/2012 and the Agreement on a Unified Patent Court. 


\section{$1 \quad$ Introduction}

In the European Union (EU), a market of more than 446 million people, the protection of inventions can be made in two ways. Twenty-seven distinct national patents can be obtained, one for each EU Member State. This implies applying and enforcing them separately on a State by State basis, or, since the implementation of the European Patent Convention (EPC) in 1978, it is possible to file a single patent application at the European Patent Office (EPO) in Munich and designate all the EU Member States in that application. Even so, utilizing this last option still necessitates enforcement of the patent separately on each State. In comparison China, India, the United States of America (USA), Brazil and Japan each has a single national patent that serves populations of 1.34 billion, 1.2 billion, 328 million, 216 million and 127 million respectively. Currently in the EU a unitary patent does not exist, which causes a delay in its development. Patents are recognised as a driving force for promoting growth, competitiveness, and innovation. Therefore, the lack of an EU patent system weakens its economy and development.

When the European Economic Community (EEC) was founded, in 1957, with the aim to "ensure the economic and social progress of their countries..., to strengthen the unity of their economies and to ensure their harmonious development..., to confirm the solidarity which binds Europe..., to preserve and strengthen peace and liberty, and calling upon the other peoples of Europe who share their ideal to join in their efforts" 1 , there was no reference in the Treaty of Rome regarding the protection of intellectual property rights.

At that time, the intellectual property rights in the EEC still had a national dimension and effects. This was considered detrimental to the objective of reaching an internal market in the EEC. Accordingly, as observed by Philip Soo (2012: 66), "it can be shown that the absence of a unitary patent right in Europe severely damages economic integration, which is central to the EU itself', and patent law has long been recognised as an economic policy instrument (Nordhaus, 1969).

\footnotetext{
${ }^{1}$ Treaty establishing the European Economic Community (Treaty of Rome), Preamble.
} 
The exceptions to the free movement of goods prescribed in Article 36 (Treaty of Rome), especially those resulting from the protection of industrial property rights, did not allow the creation of a single market and a solution to this problem had to be found.

At an international level, in 1970, the Patent Cooperation Treaty (PCT) has advanced towards a harmonisation, by allowing through one patent application to file an "international" patent application that has a simultaneous effect in several countries. Following the PCT model, the EEC created its own model of a regional patent system, the European Patent Convention (EPC) signed in Munich in 1973.2 The EPC, that entered into force in June 1978, established a multinational system for granting parallel patent rights in any of the designated countries participating in the Convention. ${ }^{3}$ The most important advantages of this system, which implemented a centralised grant procedure in one of three official EPO languages (German, French and English), are both a reduction of costs and a comprehensive prior art search and examination.

The EPC patent, issued by the EPO, has the same effect and is subject to the same conditions as those granted by a national patent office from an EU Member State. Using the EPC patent grant system is optional; thus, each inventor can choose to use either the EPC patent or directly file a patent application in different national patent offices.

In this article our first objectives are to characterise the current patent system situation in the EU and to identify the main problems existing in that model. We will then analyse the project to create the European Unitary Patent, with particular focus on examining the implementation of the Unified Patent Court and on both its virtues and disadvantages. We will defend the need for the Unified Patent Court as not only a solution for the existing litigation problems but also to ensure global judicial coherence and legal certainty of the European Unitary Patent.

\footnotetext{
${ }^{2}$ Convention on the Grant of European Patents (European Patent Convention), of 5 October 1973 as revised by the Act revising Article 63 EPC of 17 December 1991 and the Act revising the EPC of 29 November 2000.

${ }^{3}$ Idem, Article 67(1).
} 


\section{Problems with the European Patent Convention}

The EPC system is expensive and complex. To be effective, each granted national EPC patent must be validated in each Member State (paying a national fee, complying with local requirements, and providing translations of the patent or at least the claims, in accordance with the London Agreement). To keep the EPC patent in force, national renewal fees have to be paid annually, on a State by State basis. Regarding the national renewal fees, these vary considerably across the EU. In some States, payment of renewal fees is still not possible by bank or computer transfer. The deadlines for payment also differ among Member States and the communications must be in the local language. In addition, some States require a patent attorney, or equivalent profession, to deal with renewals.

The costs of obtaining and maintaining an EPC patent protection in Europe are higher than in the USA, Japan or China (due mainly to translation costs, national fees and expenses with national agents) and it becomes much more expensive when it comes to enforcement (Soo, 2012: 66; Glazer, 2015: 25).

The enforcement system founded on State by State basis is very expensive and time consuming, and many case courts in different European States have ruled differently on the meaning and effect of national EPC patents (Soo, 2012: 55-56; Baldan, 2015: 384-386). Based on the same facts, different national courts have arrived at opposite conclusions, which causes great uncertainty. ${ }^{4}$

Other problems stem from the fact that the EPC operates outside of the framework of the Treaty of Rome, that it has 38 members and not only the 27 EU Member States, and that the EPO is not an EU institution.

Several problems can be detected regarding the EPC's jurisdictional system. First and foremost is the absence of a unified central court system. Without a unified central court, as we will analyse, the patent system will be based on legal uncertainty, juridical insecurity and procedural delay.

\footnotetext{
${ }^{4}$ E.g. Improver Corp. v. Remington Consumer Products Ltd. [1990] F.S.R. 181; Gerechtshof The Hague, 1993, GRUR Int. 252-Epilady XII; UK Court of Appeal, 21 ICC 561(1990) Epilady United Kingdom II; UK Patents Court, (1990) F.S.R. 181=21 ICC 860 (1990) - Epilady United Kingdom II; Dusseldorf Court of Appeal, 1993, GRUR Int. 242-Epilady VIII.
} 
Secondly, we highlight the fact that the EPC patent jurisdictional system is based on national courts with different legal traditions (some of which have already granted cross-border court rulings), which also causes legal uncertainty, juridical insecurity and procedural delay.

Thirdly, given the need to use the Brussels Convention on jurisdiction and the enforcement of judgments in civil and commercial matters ${ }^{5}$ (Brussels Convention), the Convention on jurisdiction and the recognition and enforcement of judgments in civil and commercial matters ${ }^{6}$ (Lugano Convention), the Council Regulation (EC) No 44/2001 of 22 December 2000 on jurisdiction and the recognition and enforcement of judgments in civil and commercial matters ${ }^{7}$ and Regulation (EU) No 1215/2012 of the European Parliament and of the Council of 12 December 2012 on jurisdiction and the recognition and enforcement of judgments in civil and commercial matters respectively ${ }^{8}$ (Brussels Regulation), it is necessary to use the general rule of jurisdiction established there, actio sequitur forum rei, which is based on the criterion of domicile and which declares that, regardless of the nationality of persons, they must be sued before the national courts of the Contracting State where they are domiciled. If there are several persons infringing the patent, the patent holder may initiate various proceedings, choosing from among the States in which the counterfeiters live, the States he deems most advantageous from the point of view of judicial strategy, thus encouraging forum shopping. Therefore, the current judicial litigation of the EPC system leads to the adoption of a forum shopping mechanism whereby, given the existing legal diversity, the parties will choose as the competent forum the State in which they believe will best serve their objectives. If, for example, they want a slower process (the alleged infringer of the patent) or a faster process (the owner of the patent), considering local procedural instruments, the choice of courts will vary. As stated by Philip Soo (2012: 67) "a duplicative and internally inconsistent patent system results in legal uncertainty and encourages forum shopping", with all the problems resulting of this situation, especially the fact of the unpredictability of the judicial decisions.

\footnotetext{
${ }^{5}$ OJ L 299, 31. 12. 1972, p. 32-42.

${ }^{6}$ OJ L 339, 21. 12. 2007, p. 3-41.

7 OJ L 12, 16. 1. 2001, p. 1-23.

${ }^{8}$ OJ L 351, 20. 12. 2012, p. 1-32.
} 
In the USA, in the 1970s, there was a constant use of forum shopping with its consequential uncertainty and disparity in patent court decisions. This, in turn, caused a reduction in investments in $\mathrm{R} \& \mathrm{D}$. The creation of the United States Court of Appeals for the Federal Circuit (CAFC) in 1982 had, as its main justification, the need to ensure consistency, more predictability and confidence in court decisions. In these terms, the resulting safety has led to a marked increase in technological development (Rader, 2001: 7). With the creation of the CAFC, the forum shopping in the USA was reduced and companies began to initiate legal actions in the states where their headquarters were located. The creation of the CAFC significantly reduced the forum shopping and harmonised jurisprudence regardless of the geographical area of the court. These developments have positive impact on the mind-set of USA companies regarding patents and now patents again are considered legal instruments that protect their interests. The CAFC brought uniformity and strength to the patent. As a result of the creation of the CAFC, the value of patents increased, companies invested more in $\mathrm{R} \& \mathrm{D}$ and technological innovation grew in the USA (Kihara, 2000: 14). Before the creation of the CAFC, the jurisdiction of the regional circuits over patent law issues created several problems similar to those now encountered in the EU. Different interpretations of substantive aspects of patent law and different decisions for similar cases created a lack of consistency and uniformity.

Concerning the EPC patent litigation, initially the Brussels Convention and currently the Brussels Regulation, allows the competent court to be one of the following: the court of domicile; ${ }^{9}$ in non-contractual matters, the court of the State where the harmful event occurred; 10 if there are several defendants, the court of domicile of any one of them; ${ }^{11}$ in the matter of patent registration or validity, the court of the State which granted the patent. ${ }^{12}$ These rules, combined with those concerning pendency and connection of processes, ${ }^{13}$ allow for an expansive choice of the forum in which the action can be brought.

\footnotetext{
${ }_{9}^{9}$ Brussels Convention, Article 2; Brussels Regulation, Article 5.

${ }^{10}$ Brussels Convention, Article 5(3). Brussels Regulation, Article 7(2). As defined by the Court of Justice of the EU (CJEU) in case C-68/93, Fiona Shevill, Ixora Trading Inc., Chequepoint SARL and Chequepoint International Ltd v Presse Alliance SA, ECLI:EU:C:1995:61, the place where the harmful event occurred may be the place where the action was initiated or where it occurred, but not the place where the indirect effects of the event occurred.

${ }^{11}$ Brussels Convention, Article 6(1); Brussels Regulation, Article 8(1).

12 Brussels Convention, Article 16(4); Brussels Regulation, Article 24(4).

${ }^{13}$ Brussels Convention, Article 21, 22; Brussels Regulation, Article 29 and 30.
} 
The disparity of decisions resulting from forum shopping made it difficult to calculate the patent value that depends on the ultimate location of an infringement suit, which is an unpredictable factor. Also, this judicial patent litigation system leads to a community-wide exhaustion of patent rights.

A fourth problem arises from the existence of different national procedural laws concerning patent proceedings (Gall, 1998: 140). Twenty-seven States with different procedural laws will invariably lead to different solutions and are an incentive to forum shopping.

A fifth problem is that in some States, infringement and validity cases are tried in separate cases and in different courts while in other States these situations are tried in the same case and court. Germany, for instance, has different courts dealing with infringement and validity issues separately, which can lead to the situation that for the same patent one court decides there has been infringement whereas the other court later invalidates that same patent.

A sixth problem results from the fact that some jurisdictions are not specialised, and the patent cases in those States are tried by courts of general jurisdiction (e.g. Ireland and Latvia); some States have specialised national courts (e.g. the Portuguese Tribunal da Propriedade Intelectual); others have created specialised sections within national or district generalist courts (e.g. the Dutch Rechtbank); and still others have established generalist sections to resolve intellectual property questions (e.g. the Italian Sezioni Specializzate in Materia di Impresa).

The most serious problems of the EPC patent result from the European patent litigation system. An action for an EPC patent must be brought before a national court, with the great possibility that different sentences will emerge, in different States, for the same situation.

Despite all the problems, the EPC patent has been highly successful (Soo, 2012: 6162; Pitkethly, 1999: 6). Yet, it is a system criticised by many authors. From the founders of the system, such as $V$ an Benthen (1993), to authors like Tootal (1995), $W$ adlow (1998), or Cremers (2017) the criticism of the present system is manifold, underlining essentially criticisms pertaining to cost, translation and litigation. 


\section{European Unitary Patent}

The EEC founding Member States soon realised that having separate patents for each European State would be complex and expensive and could frustrate the creation of an internal market (Straus, 1997: 9-10; Tilmann, 2012: 87-88).

The EPC, signed in 1973, in reality became a bundle of national patents in all the States designated in the application, that need to be validated at the national level (Wadlow, 1998: 214; Gómez Segade, 1998: 1159; Baldan, 2015: 385). However, a serious drawback is that it fails to allow for the creation of an internal market. To try to solve this problem, in 1975 the nine EEC Member States signed in Luxembourg, the Community Patent Convention (CPC). The CPC envisaged the creation of a single, uniform, community-wide patent being granted as the result of an application to the EPO. This Convention was never ratified by enough signatory States, and accordingly never went into force. In 1989, there was an attempt to revive the CPC, but it was not ratified either. The Community Patent Litigation Protocol to the 1989 Convention predicted to use the national courts as First Instance Community Patent Courts for infringement procedures. It was also expected to create a Second Instance Community Patent Court for appeals from the first instance decision, and a Community Patent Appeal Court (COPAC) to which the Second Instance Community Patent Court had to refer the infringement and validity. Since then, many authors have argued that the CPC was not a good solution to create a patent for the EEC and that the preferable solution would be an EEC Regulation and not an international convention (Tilmann, 2012: 89).

In 1997, the Commission published the Green Paper on the Community Patent and the Patent System in Europe. ${ }^{14}$ The Green Paper argued that the legal instrument to be used to create the Community Patent should be an EEC Regulation, and in 2000 the Commission presented its proposal of a Regulation for a Community Patent. ${ }^{15}$ This Regulation proposal led to an important debate on the creation of the Community Patent, but for a number of reasons including translation requirements, fees and in particular the lack of agreement on the model of jurisdictional control of the patent (Lucas, 2009: 546-547), this proposal was never approved.

\footnotetext{
${ }^{14}$ COM (97)0314.

${ }^{15}$ COM (2000) 412 final.
} 
In 2010, the "Europe 2020 - A Strategy for Smart, Sustainable and Inclusive Growth", ${ }^{16}$ again renewed the discussion regarding the need not only for a unitary patent right for the EU but also for a dedicated patent court to enforce this unitary patent right. In an effort to establish a European Unitary Patent (EUP), two regulations were approved. The first was to address the question concerning, inter alia, how a Unitary Patent could be obtained (Regulation (EU) No 1257/2012 of the European Parliament and of the Council of 17 December 2012 implementing enhanced cooperation in the area of the creation of unitary patent protection ${ }^{17}$ (Regulation EU 1257/2012). The second was to deal with translation requirements (Council Regulation (EU) No 1260/2012 of 17 December 2012 implementing enhanced cooperation in the area of the creation of unitary patent protection with regard to the applicable translation arrangements ${ }^{18}$ (Regulation EU 1260/2012). With the same purpose it was also approved the Agreement on a Unified Patent Court $^{19}$ (AUPC).

The new patent will not be applicable in all 27 EU Member States. Croatia and Spain have chosen not to participate in the Unitary Patent project, and the Council of Ministers of the EU, having heard the European Parliament, decided to authorise the other 25 Member States to implement an enhanced co-operation in the area of Unitary Patent Protection, under Article 20 of the Treaty on the European Union. ${ }^{20}$

This new legal framework intends to solve the main problems of the European patent (easy and not expensive translation, reduced costs, simplified procedures, and the adoption of the Unified Patent Court). The Regulation EU 1257/2012, Article 2(c), calls the new patent "European patent with unitary effect", known as European Unitary Patent (EUP). The new EUP will still be granted by the EPO under the rules and high standards of quality search and examination of the EPC. After this patent is granted the applicant will be able to request unitary effect, thus securing a EUP which provides uniform patent protection in up to $25 \mathrm{EU}$ Member States. The EUP will have a unitary effect to that patent throughout all the participating States and

\footnotetext{
${ }^{16}$ COM (2010) 2020 final.

17 OJ L 361, 31. 12. 2012, p. 1-8.

18 OJ L 361, 31. 12. 2012, p. 89-92.

${ }^{19}$ OJ C 175, 20. 6. 2013, p. 1-40.

${ }_{20}$ On 10 March 2011, the Council adopted Decision 2011/167/EU authorizing enhanced cooperation in the area of the creation of unitary patent protection (OJ L 76, 22. 3. 2011, p. 53-55).
} 
will eliminate the need to seek separate validation in each country where protection is sought.

The procedures for obtaining an EPC patent and a EUP will be the same until validation. Thereafter, the EUP applicant will have the option to forego national validation or choose protection in all EU Member States and will be able to secure patent protection in $25 \mathrm{EU}$ Member States.

The EUP adopted in February 2013 has not entered into force yet and the start of the new system is currently expected for the end of 2020. In reality, the EU Regulations (1257/2012 and 1260/2012) entered into force on 20 January 2013, but these two Regulations will only apply as from the date of entry into force of the AUPC. ${ }^{21}$

When in operation, the EUP will not replace the existing EPC patent or the national patents. The applicant can choose which of the three different patents (national, EPC or EUP) to request.

As stated before, the main problem with the current system, the lack of a system of juridical control, can be solved with the creation of a Unified Patent Court (UPC). Until the entry into force of the AUPC, the EUP cannot enter in force either.

\section{$4 \quad$ Unified Patent Court}

Under the existing EPC patent system, there is the need for a multiplicity of separate national actions, one in each European State, especially at a jurisdictional control level. One of the main objectives of the EUP is to avoid this situation and for that purpose the UPC needs to be created (Clay, 2012: 17).

\footnotetext{
${ }^{21}$ Which is on the first day of the fourth month after the deposit of the thirteenth instrument of ratification or accession, including the three Member States in which the highest number of European patents had effect in the year preceding the year in which the signature of the Agreement takes place or on the first day of the fourth month after the date of entry into force of the amendments to Regulation (EU) 1215/2012 concerning its relationship with this Agreement, whichever is the latest (Article 89(1) of the AUPC).
} 
In this regard, the England and Wales High Court stated in the case Leo Pharma A/S and Leo Laboratories Ltd. v. Sandoz Ltd. "Different results in different countries based on different cases is, of course, explicable. It is an unfortunate state of affairs, curable only by a single European Patent Court" 22 confirming the great uncertainty existing around this matter.

The EUP was envisioned decades ago in Article 142 of the EPC, that predicted the possibility for a group of contracting States to provide a patent right having "unitary character throughout their territories", a solution which was idealised at CPC to be enforceable over the entire European Community, but it was never approved.

In 2001, concerning the Community (EU) design, which has problems that are common to those of the unitary patent, the Council Regulation (EC) No 6/2002 of 12 December 2001 on Community designs ${ }^{23}$ created "a unified system for obtaining a Community design to which uniform protection is given with uniform effect throughout the entire territory of the Community", with the implementation of a jurisdictional system.

After the signature of the Treaty of Lisbon amending the Treaty on European Union and the Treaty establishing the European Community ${ }^{24}$ (Lisbon Treaty) in 2007, the European Patent Court project was discussed again, and based on its interpretation of Article 118, the Commission constructed a draft agreement and statute for the Patent Court.

Approved in 2013, the AUPC is comprised of a Court of First Instance, a Court of Appeal (will be located in Luxembourg) and a Registry (Article 6 of the AUPC). The Court of First Instance is divided into a Central division, Local divisions (for each State party), and Regional divisions (two or more State parties, only if they prefer to establish a common division) (Article 7 of the AUPC).

\footnotetext{
${ }^{22}$ Leo Pharma A/S and Leo Laboratories Ltd. v. Sandoz Ltd., EWCA Civ. 118, 2009.

${ }^{23}$ OJ L 3, 5. 1. 2002, p. 1-24.

${ }^{24}$ OJ C 306, 17. 12. 2007, p. 1-271.
} 
The central division consists of two legally qualified judges who are nationals of different Contracting Member States and one technically qualified judge allocated from the Pool of Judges in accordance with Article 18(3), with qualifications and experience in the field of technology concerned (Article 8(6) of the AUPC). This option for the integration of professional judges, with knowledge in a specific field of technology, will allow the courts to gain significant stature and knowledge, and will contribute to both higher quality and faster decisions. The EU is following the USA model, relying on judges with specialised training in patent law and technology to preside over infringement disputes (Harnett, 2013: 15).

Regional divisions can be established at the request of two or more signatory States, who will designate the seat of the division concerned (Article7(5) of the AUPC). A local division shall be set up in a Contracting Member State upon its request in accordance with the Statute (Article 7(3) of the AUPC).

The Patent Court structure, with a division of responsibilities (the central division will be in charge of the enforcement of patents, and local and regional divisions will address infringement, provisional and protective measures and injunctions, damages or compensation derived from provisional protection and/or prior use (Chapter VI of the AUPC)), aims to make it more efficient and faster.

With this system we will find a specialised UPC, with trial and appellate levels, and the CJEU with generalist competences to decide on unitary and European patent issues. The option to locate court venues distributed by the Member States, including a range of local, regional and central divisions, allows the UPC to achieve a balance between, on the one hand, legal certainty resulting from centralised judgment and, on the other hand, the benefits achieved through a local patent dispute judgment.

The option to create a specialised European patent court is similar to the decision of the United States Congress in 1982 to create the CAFC which is a court of appeal with jurisdiction over all USA patent appeals. As observed by Harnett (2013: 17), with the creation of the CAFC "the development of consistent substantive law increases the value of US patents, allowing companies to invest in innovation and research and development with more certainty regarding the potential value and enforcement of their patents." The same can happen in the EU with the creation of 
the UPC. With the centralisation of decisions, and technically qualified judges, the decisions should be of higher quality, be more secure and faster.

The UPC will have jurisdiction over EUP and EPC patents and intends to harmonise the scope and limitations of the rights conferred by a patent, and remedies available beyond EU Directive 2004/48/EC25 (Enforcement Directive).

Specifically, the UPC will have exclusive jurisdiction in the court proceedings listed under Article 32(1) of the AUPC (e.g. patent infringement proceedings, actions for revocation of patents and provisional injunctions for both unitary patents and classical European patents) and all other proceedings (actions relating to patents and supplementary protection certificates which do not come within the exclusive competence of the UPC) will be handled by national courts (Article 32(2) of the AUPC).

The UPC jurisdiction will also encompass the actions related to EPC patents. During a transitional period of seven years the patent owners of classical EPC bundle patents can choose the UPC or national courts (Article 83 of the AUPC).

The EPO identifies that the main objectives of the UPC are:

- "- establish an effective forum for enforcing and challenging patents in Europe,

- end the need for litigation in different countries;

- enhance legal certainty through harmonised case law in the area of patent infringement and validity;

- provide simpler, quicker and more efficient judicial procedures; and,

- harmonise substantive patent law relating to the scope and limitations of the rights conferred as well as the remedies in cases of infringement". ${ }^{26}$

\footnotetext{
${ }^{25}$ Directive 2004/48/EC of the European Parliament and of the Council of 29 April 2004 on the enforcement of intellectual property rights (OJ L 195, 30. 4. 2004, p. 45-86).

${ }^{26}$ https://www.epo.org/law-practice/unitary/upc.html (accessed: 2. 5. 2020).
} 
To achieve these goals Article 24 of the AUPC determines that when hearing a case, the Court shall base its decisions on:

“(a) Union law, including Regulation (EU) No 1257/2012 and Regulation (EU) No 1260/2012;

(b) this Agreement;

(c) the EPC;

(d) other international agreements applicable to patents and binding on all the Contracting Member States; and

(e) national law".

Besides these, Article 24(3) of the AUPC allows the possibility of the law of NonContracting States to be applied when designated by application of the rules referred in Paragraph 2, which regulates the application of national laws in the UPC.

One of the major innovations of the UPC will be the creation of a patent mediation and arbitration centre (Article 35 of the AUPC). In patent disputes, parties increasingly submit disputes to mediation, arbitration or any other Alternative Dispute Resolution (ICC Intellectual Property Roadmap, 2017: 64), and the UPC system intends to respond to this reality. The Centre will have two seats, one in Ljubljana and the other in Lisbon (Article 35(1) od the AUPC), and will be financed by the budget of the Court (Article 39 of the AUPC). The Centre shall establish the Mediation and Arbitration Rules (Article 35(3) of the AUPC). Since Portugal and Slovenia are both parties to the 1958 New York Convention on the Recognition and Enforcement of Foreign Arbitral Awards, the choice of Lisbon or Ljubljana to start the arbitration process will allow parties to benefit from the New York Convention's advantages in terms of global enforceability.

The main provisions in relation to mediation/arbitration and settlements in the AUPC are as follows: Article 35(2) states that "Article 82 shall apply mutatis mutandis to any settlement reached through the use of the facilities of the Centre, including through mediation", confirming the enforceability of settlements reached through the use of the facilities of the Centre, and Article 79 allows the parties "at any time in the course of proceedings, conclude their case by way of settlement, which shall be confirmed by a decision of the Court". 
A significant limitation to this option is that "...a patent may not be revoked or limited in mediation or arbitration proceedings" (Articles 35(2) and 79 of the AUPC). This article limits the use of mediation or arbitration to settle patent disputes given that they cannot decide on the validity nor the scope of a patent. This is not, however, an absolute limitation. The objective of the EUP is to be a unitary patent. To achieve that goal, the effects of a decision of the UPC must be erga omnes. The decision to revoke a patent, entirely or partly, should be reflected in the relevant patent registry (EPO or national patent office) (Article 65(5) of the AUPC), and should have binding effects upon third parties. However, if a decision of the arbitral tribunal has binding effects only inter partes, and if it does not affect third parties or otherwise affect the validity and registry of the patent for third parties, it is then under those circumstances possible to have an arbitral decision on the validity of a patent. An example of such a situation would be in a litigation about a patent license agreements, with effect only inter partes. ${ }^{27}$

Regarding mediation, considering its objectives, Article 35(2) of the AUPC seems to be too restraining for the cases where the patent owner agrees on revocation or limitations upon the patent within the scope of the mediation process. In this path, the preliminary version of the "Rules of Procedure of the UPC" 28 (RoP) confirms the possibility, that during a mediation or arbitration process, the patent owner agrees to revoke or limit his patent. Rule 11(2) of the RoP states that "Pursuant to Rule 365 the Court shall, if requested by the parties, by decision confirm the terms of any settlement or arbitral award by consent (...), including a term which obliges the patent owner to limit, surrender or agree to the revocation of a patent or not to assert it against the other party and/or third parties". Rule 365(1) of the RoP asserts that "Where the parties have concluded their action by way of settlement, they shall inform the judge-rapporteur. The Court shall confirm the settlement by decision of

\footnotetext{
27 The USA have a similar solution under the US Patent Act (35 U.S.C. 294) which states that: “(a) A contract involving a patent or any right under a patent may contain a provision requiring arbitration of any dispute relating to patent validity or infringement arising under the contract. In the absence of such a provision, the parties to an existing patent validity or infringement dispute may agree in writing to settle such dispute by arbitration...." and that "(c) An award by an arbitrator shall be final and binding between the parties to the arbitration but shall have no force or effect on any other person. The parties to an arbitration may agree that in the event a patent which is the subject matter of an award is subsequently determined to be invalid or unenforceable in a judgment rendered by a court of competent jurisdiction from which no appeal can or has been taken, such award may be modified by any court of competent jurisdiction upon application by any party to the arbitration...".

${ }^{28}$ https://www.unified-patent-

court.org/sites/default/files/upc_rules_of_procedure_18th_draft_15_march_2017_final_clear.pdf (accessed 4. 5. 2020).
} 
the Court [Rule 11.2], if requested by the parties, and the decision may be enforced as a final decision of the Court". According to these rules, once approved by the UPC, a settlement that revokes totally or partly one patent, can be valid, despite the provisions of Article 35(2) of the AUPC. This system resulting from the AUPC and the RoP, will allow settlements to indirectly have effect on third parties on the subject of validity or limitation of patents.

A mediation or arbitration case may be submitted to the Centre during the proceedings before the UPC. It is unclear whether a submission to the Centre is possible before the litigation process is submitted to the UPC. Article 35(2) states that "the Centre shall provide facilities for mediation and arbitration of patent disputes falling within the scope of this Agreement", and does not set forth explicit requirements for this option. Accordingly, it is believed that the facilities of the Centre may be used prior to any judicial procedure, in a conventional situation (application of a mediation/arbitration clause) where parties want to settle their dispute by mediation and/or arbitration. However, this solution of opting for the UPC Mediation and Arbitration Centre does not prevent the parties from choosing any arbitration institution or even creating an ad hoc procedure to resolve the conflict. In fact, if the parties decide to submit their dispute to arbitration, the UPC is bound by this choice and must decline its jurisdiction if the action, respecting the arbitration clause that defines the nature and scope of the disputes, would fall within the jurisdictional power of the arbitral tribunal.

To conclude this brief analysis of the UPC, we refer to a recent study, based on a newly gathered dataset of empirical patent case data showing that the existence of the UPC will reduce duplicative court cases across different European jurisdictions and defends the potential benefits of the UPC concluding that: "(i) the centralisation of patent cases via the UPC will reduce differences in legal procedures concerning patent enforcement across various European jurisdictions, giving litigants greater legal clarity regarding procedures"; "(ii) the UPC may also increase the speed of decision-making..."; "(iii) the existence of UPC litigation will level the costs involved in patent proceedings..."; "(iv) the UPC will in the long term eliminate the need for parallel litigation involving EPs and Ups..."; and "(v) the UPC may therefore facilitate an increase in the unity of patent settlements across Europe, cutting down on situations where a settlement is reached in one jurisdiction, but litigation continues in the other(s)" (Cremers, 2017). This study generated extensive 
empirical evidence on patent litigation analysis in Europe and concludes that the UPC will result in many potential benefits including a decreased of the costs and the development of uniform jurisprudence with reduced risk of diverging decisions.

\section{$5 \quad$ European Unitary Patent and Unified Patent Court future problems}

The UPC represents a significant advance in the pursuit of the EUP, but there are still some legal, practical and political problems left to discuss.

Once up and running we will find different levels of judicial or quasi-judicial decisions. In the States which are not part of the AUPC, national judges will still be able to decide on European patent litigation. Both situations will cause a problem of lack of coherence. With the entry in force of the UPC, the European patent system will be reshaped and will have several more actors in this complex multilevel governance structure.

One main objective of this new patent system is to obtain judicial coherence. As summarised by Baldan (2015: 381-383), there are several types of judicial coherence: horizontal coherence "in legal systems has primarily been used to explain the coordination of the policies of the different Community pillars"; vertical coherence "has been employed to describe the need for consistency between policies of the EU Member States and the EU"; global coherence "justified decisions are those which best cohere with the law as a whole" and local coherence "focuses on whether decisions are supported by principles that are special to a specific legal field". There is presently no guarantee that these different types of coherence will be achieved.

The lack of coherence in the EUP is visible in the legislative competence level. The EPO Member States, at an international level, have adopted the EPC, the Paris Convention for the Protection of Industrial Property, signed in Paris, in 1883, the PCT and the Agreement on Trade-Related Aspects of Intellectual Property Rights (TRIPs), signed in Marrakesh, in 1994. The EU have issued patent legislation on specific issues such as biotechnological inventions ${ }^{29}$ and patent enforcement (Enforcement Directive). Also, the EU Member States have issued patent legislation. The lack of coherence from an administrative point of view is visible since the EUP

\footnotetext{
${ }^{29}$ Directive 98/44/EC of the European Parliament and of the Council of 6 July 1998 on the legal protection of biotechnological inventions (OJ L 213, 30. 7. 1998, p. 13-21).
} 
will be administered by the EPO, an organisation that was created by an international convention including all EU Member States and several other States (e.g. Switzerland, Turkey, Norway), and for that reason it is not an EU institution or agency, which can lead to conflicts between EU Member and non-EU Member States.

The Boards of Appeal of EPO, a quasi-judicial branch of the EPO, are responsible for examining appeals against decisions taken by the Office. They will decide on the decisions of the EPO Opposition Boards on the revocation of granted patents. Additionally, national patents are granted by the national patent offices and for EPC patents it is the EPO which is responsible for the examination. This divergence of responsibility points to the possibility of lack of coherence.

From a judicial point of view, under this new system there will be a specialised court, the UPC, and a generalist court, the CJEU, and they will need to cooperate in deciding on unitary and European patent issues. Their failure to do so may well cause a lack of coherence in the system.

The creation of the UPC does not replace the existing actors and will add an additional layer of jurisdiction, which in turn can lend greater complexity to an already fragmented European patent litigation system. There will be national judges with different judicial systems, the EPO, the Boards of Appeal of the EPO, the UPC and the CJEU issuing patent decisions and thus creating patent doctrine.

The judiciary (UPC, national courts and the CJEU), the quasi-judiciary (the Boards of Appeal of EPO) and the executive (the EPO Examination and Opposition Divisions) will result in a tri-partite system that may raise questions in terms of checks and balances between different powers and judicial coherence and legal certainty.

Since the cases will be allocated to one of the three separate locations of the central division of the Court of First Instance, depending upon the particular sectors/technologies (Article 7(2) and Annex II of the AUPC), there also is a possibility that each one of the three divisions will create different patent doctrine for those particular sectors/technologies. 
The first and second versions of the CPC $(1975,1989)$ already included a relationship between the CJEU and European patent court. ${ }^{30}$ This relationship remains in the AUPC that states (Article 21) that the UPC as a court common to the Contracting Member States and as part of their judicial system "shall cooperate with the CJEU to ensure the correct application and uniform interpretation of Union law, as any national court, in accordance with Article 267 Treaty on the Functioning of the European Union ${ }^{31}$ (TFEU) in particular".

The relationship between the UPC and the CJEU is important in ensuring global coherence of the EU law and to avoid patent law standing in isolation to other EU law. However, the CJEU is a generalist court and the UPC is a specialised court. The UPC, in its decisions, can marginalise other interests (e.g. competition law) and focus only on patent law. The CJEU can have a broader vision and does not protect only the interests of patent owners. Also, the CJEU will have to provide its interpretation on very technical issues such as, for example, biotechnological inventions or supplementary protection certificates. Since it is the UPC Court of Appeal that will choose the cases to present to the CJEU, the extent of involvement by the CJEU will mainly depend on the UPC Court of Appeal choices. This uncertainty may further undermine the legal certainty regarding the patent.

Another problem that can arise with the creation of UPC is that forum shopping can still be possible at a court of First Instance level. Local divisions can start to develop their own practice (e.g. pro-patentee) in order to attract cases (Xenos, 2013), and then parties will choose different UPC divisions to start infringement proceedings according to their interests (Article 33 of the AUPC). While that is a drawback, the corresponding advantage is that it will not be possible to forum shop at a State level.

\footnotetext{
${ }^{30}$ European Patent Litigation Agreement (Draft "European Patent Litigation Agreement" of 20 April 2004, EPO, Working Party "Litigation"), the Community Patent Regulation ("Proposal for a Council regulation on the Community Patent" COM (2000) 412 final, OJ C 337 E) and the European and EU Patents Court Agreement ("Draft Agreement on the European and Community Patents Court and Draft Statute - Revised Presidency text" Council of the EU, 23 March 2009, 7928/09).

31 OJ C 326, 26.10.2012, p. 47-390.
} 
Some problems will arise from the fact there are some EU Member States that are not members of the UPC. The EUP will have national judges presiding over European patent litigation in those States which are not part of the AUPC. The fact that it was necessary to use the enhanced cooperation procedure, under Article 20 of the Treaty on the European Union, proves the difficulty in finding a common solution. The nationals of the States that do not participate in the AUPC may use the system for EUP in the geographical area of the Agreement. Under this solution, the EU is not a member of the AUPC, but it is important to insert an accession clause to allow the EU to be a member at a later point in time.

Another issue will arise from the fact that States outside the EU cannot access the AUPC; only EU Member States can do so.

There are also some practical problems that will result from the entry into force of the UPC. After its implementation, during the transitional period of seven years, the European patents owners can choose whether or not to use the new system (Article 83(3) of the AUPC). They can opt out of the UPC and maintain their ability to litigate in national courts. This raises the question of who chooses the system where to litigate: the patent owner, or the defendant with his revocation claim? There is no clear answer for that question. Ultimately, the first party to the suit will dictate where to file suit, which will further foster some degree of legal uncertainty.

Another practical problem is the fact that this court needs experienced, legally and technically qualified judges that can ensure the highest standards of competence. These judges also should have proven experience in the field of patent litigation along with foreign language competences. To achieve these goals, in 2016 the Preparatory Committee of the UPC launched a major recruitment campaign for judicial positions (legal and technical) and again in 2019 it has re-opened the recruitment for judicial positions to new applications. ${ }^{32}$ In 2012, Tilmann (2012: 98) argues that it will be difficult to find qualified judges. However, in the 2016 recruitment campaign a total of 840 applications were submitted, 280 applicants interviewed, with the goal to appoint 45 legal and 50 technical judges in permanent position. The appointment procedure of the judges can only be completed after

\footnotetext{
32 https://www.unified-patent-court.org/news/upc-judicial-recruitment-2019-top-campaign-now-open (accessed: 2. 5. 2020).
} 
entry into force of the Protocol on Provisional Application and subsequently the AUPC. For that reason, it will be important to choose the new judges and start the training before the AUPC goes into operation.

One final problem is the fact that to enter in force the AUPC must be ratified by at least 13 States, including Germany, France and the United Kingdom, which are the three largest patent-granting States taking part in the EU agreement. The recent decision of the German Federal Constitutional Court (Order 13 February 2020, 2 BvR 739/17), to declare void the Bundestag's Act of Approval to confer sovereign powers on the UPC, stopped this process of ratification and will request a new vote from the Bundestag.

Fortunately, the German Court's negative decision is not premised upon the content of the agreement but rather a procedural issue which, we hope, can be overcome. The Act of Approval should have been approved with a qualified majority (twothirds) in the Bundestag but failed to do so because it was adopted unanimously in the third reading but only by about 35 members of the chamber. Hopefully, this essentially technical problem is possible to resolve with a new vote in the Bundestag.

\section{Conclusion}

The long story of EUP creation seems to be reaching an end. Since the 1970s, right after the EPC creation, several attempts were made to create a unitary patent and a centralised patent jurisdiction. ${ }^{33}$ The three well-known major problems: high costs, translation requirements and the creation of common system of litigation seem to be almost solved.

The EUP will reduce costs by providing a single, EU-wide enforceable patent with new rules for translation requirements for protection in each EU Member State along with the elimination of the current system of each country-specific validation. The applicable translation arrangements for protection in each EU Member State found a solution for the language regime with a transitional period and

\footnotetext{
${ }^{33}$ Community Patent Convention 1975; Community Patent Litigation Protocol to the 1989 Convention; Regulation for a Community Patent (COM (2000) 412 final).
} 
compensation regime for translation costs. ${ }^{34}$ The UPC will resolve the litigation issues. The necessary legislation to solve these problems has not been accepted by all EU Member States. Accordingly, it was necessary to use the enhanced cooperation procedure, under Article 20 of the Treaty on the European Union, which proves not only the difficulty of finding consensus on this matter but also the probable challenges that lie ahead with its implementation.

The entry in force of the EUP is currently expected for the end of $2020^{35}$, after the implementation of the UPC. However, not all the EU Member States are members of the EUP and the UPC, which greatly undermines its ultimate success. Croatia and Spain have chosen not to sign the Regulation 1257/2012 (EUP), and Croatia, Spain and Poland have also chosen not to sign the AUPC. The fact that EUP will not be applicable in all EU Member States will continue to cause a situation of insecurity and legal uncertainty regarding the use of the patent in the EU.

To enter into force, the AUPC must be ratified by at least 13 States, including France, Germany and the United Kingdom, and only after the UPC is working will we have a EUP.

These requirements and the recent decision of the German Federal Constitutional Court (Order 13 February 2020, 2 BvR 739/17), to declare void the German Act of Approval of the AUPC, indicate that it will be difficult for the EUP to start operating in late 2020, as expected. The United Kingdom, one of three mandatory signatories required for the AUPC to come into force, ratified this Agreement in April 2018, with the Brexit already underway. Recently, in February 2020, a spokesperson for the prime minister declared: "The UK will not be seeking involvement in the court and the associated unitary patent", ${ }^{36}$ and the United Kingdom withdrew from the UPC system. Since the UPC will not be an EU institution, it would be possible for the United Kingdom to remain as a member of this court after the Brexit. However, the AUPC provides the possibility of appeals from the UPC to the CJEU and so the United Kingdom would stay under European jurisdiction, which is not possible. In

\footnotetext{
34 Council Regulation (EU) 1260/2012 implementing enhanced cooperation in the area of the creation of Unitary Patent protection with regard to the applicable translation arrangements (OJ EPO 2013, 132).

35 https://www.epo.org/law-practice/unitary/unitary-patent/start.html (accessed: 2. 5. 2020).

36 https://www.lawgazette.co.uk/law/government-finally-kills-uk-role-in-euro-patent-court/5103277.article, https://www.europarl.europa.eu/RegData/etudes/ATAG/2020/649575/IPOL_ATA(2020)649575_EN.pdf (accessed: 4. 5. 2020).
} 
addition to the non-ratification by Germany, the withdrawal by the United Kingdom will also delay the entry into force of the UPC, and it will be necessary to define new conditions of ratification of the AUPC.

The principal advantage of the UPC will be the harmonisation of European patent law and enforcement throughout the EU. In reality, however, it will be needed to assure judicial coherence and legal certainty between different entities: the CJEU, the UPC and the national courts with judiciary power, the Boards of Appeal of EPO with quasi-judiciary power and the EPO Examination and Opposition Divisions with administrative power. It will be important that the CJEU, the UPC and the national courts, and also the EPO, find appropriate paths to a common interpretation of patent law.

The UPC, with highly specialised judges, can create an isolated body of patent jurisprudence and give little importance to matters not related to patents. However, it is important to guarantee the basic principles of law simultaneously with the specificities of patent law. For this reason, to assure global judicial coherence, the collaboration between the UPC Court of Appeal and the CJEU is very important.

The future creation of a patent mediation and arbitration Centre (Article 35 of the AUPC) will also be an advantage for the EUP. The attractiveness of Alternative Dispute Resolution solutions (particularly in terms of confidentiality, celerity and expertise) explains why they are increasingly perceived as attractive methods for solving intellectual property disputes, especially at the global level. For the first time at the EU level, with Article 35 of the AUPC, it is officially confirmed that patent disputes can be subject to arbitration, of course subject to the limits already referred in Article 35(2) of the AUPC. Thus, even Member States that do not recognise the arbitrability of patent disputes in the national law will enforce this arbitral decision. Therefore, Article 35 extends the scope of the arbitrability of patent disputes within the EU.

The coexistence of the EUP with the structure of the UPC, the structures of EPO, the national courts and the CJEU raise possible concerns about the increase of possible legal uncertainty, increased incoherence and strategic litigation. The success of the EUP, and whether these possible downside risks can be overcome, will 
depend in large measure on a productive dialogue between all parties involved on the interpretation and application of the European patent law.

EPO will continue to maintain a very important role in the new structure of EUP, specifically in its relationship with the UPC, namely under Article 33(10) of the AUPC that allows UPC judges, in questions of pending revocation, limitation or opposition proceedings before the EPO, to request for accelerated processing before the EPO, and the UPC may stay its proceedings when a rapid decision may be expected from the EPO.

The need for a EUP has long been justified and it will make a significant contribution to the development of the EU. The EU economy (industry, companies, patent owners, defendants) has been waiting 62 years for a EUP with a common litigation system, a court system and a central appeal court. The main legal solutions have been found. The problems that remain are not overly difficult to solve. However, what is still missing are final decisions from the Commission, the Council and the Parliament. These are political decisions, and of course political decisions often are difficult and present their own challenges.

\section{References}

Baldan, F., van Zimmeren, E. (2015) Exploring Different Concepts of Judicial Coherence in the Patent Context: The Future Role of the (New) Unified Patent Court and its Interaction with other (Old) Actors of the European Patent System, Review of European Administrative Law, 8(2), pp. 377-408.

Cremers, K. et al. (2017) Patent litigation in Europe, European Journal of Law and Economics, 44, pp. $1-44$.

Clay, A. (2012) A Unified European Patent Process and a Unified Way of Enforcing It, Intellectual Property \& Technology Law Journal, 24(6), pp. 15-19.

Gall, G. (1998) Legislative and Judicial Powers in Europe - How far is harmonization of Patent Law and Practice possible and desirable?, European Intellectual Property Review, 10, pp. 138-142.

Glazer, K. (2015) Advantages and Disadvantages of the Single European Patent, Naše Gospodarstvo, 61(2), pp. 24-34.

Gómez, S. J., A. (1998) El renacer de la Patente Comunitaria y el sistema de Patentes Europeo, Actas de Derecho Industrial y Derecho de Autor, Universidad de Santiago de Compostela, Tomo XIX, pp. 1159-1171.

Harnett, C. J., Wieker, A. F. (2013) The EU Unitary Patent and Unified Patent Court: Simplicity and Standardization, Challenge, and Opportunity. Intellectual Property \& Technology Law Journal, 25(4), pp. 15-18.

ICC Intellectual Property Roadmap, 2017. https://iccwbo.org/content/uploads/sites/3/2014/11/icc-IProadmap-intellectual-propertyroadmap-current-emerging-issues-business-policymakers.pdf_accessed: 8. 5. 2020). 
Kihara, Y. (2000) U.S. Pro-Patent Policy: A Review of the Last 20 Years, CARISP Newsletter, Winter, pp. 11-17.

Lucas, E. (2009) A Patente Comunitária e o seu Controlo Jurisdicional (Odivelas: RÉSXXI Formalpress, Publicações e Marketing).

Nordhaus, W. (1969) Invention, Growth and Welfare: A Theoretical Treatment of Technological Change (Cambridge: MIT Press).

Pitkethly, R. (1999) The European Patent System: Implementing Patent Law Harmonisation, Oxford Intellectual Property Research Centre: http://www.oiprc.ox.ac.uk/EJWP1099.pdf_accessed: 4. 5. 2020).

Rader, R. (2001) Do you want your foreign patent enforced in a U.S. court?, in Hill, Kraig M., Takenaka, Toshiko e Takeuchi, Kevin, (ed.), Rethinking International Intellectual Property, CARISP Symposium Publications Series, $n^{\circ}$ 6, July.

Soo, P. P. (2012) Enforcing a Unitary Patent in Europe: What the U.S. Federal Courts and Community Design Courts Teach Us, Loyola of Los Angeles International and Comparative Law Review, 35, pp. 55-97.

Straus, J. (1997) The Present State of the Patent System in the European Union as Compared with the Situation in the United States of America and Japan, in Max Planck Institute For Foreign And International Patent, Copyright And Competition Law, https://op.europa.eu/en/publicationdetail/-/publication/ 6d8eafc6-5de1-4a36-aeb6-ef479f138fed_(accessed: 2. 5. 2020).

Tilmann, W. (2012) Moving towards completing the European Patent System: an Overview of the draft Agreement on a Unified Patent Court, ERA Forum, 13, pp. 87-101.

Tootal, C. (1995) The European Patent System: Time For Review. European Intellectual Property Review, 9, pp. 415-416.

Van Benthem, J. B. (1993) The European Patent System and European Integration, International Review of Intellectual Property, 24(4), pp. 435-445.

Wadlow, C. (1998) Enforcement of Intellectual Property in European and International Law (London: Sweet \& Maxwell).

White, K. (2013) One Patent (and Court) to Rule Them All: An Unexpected European Decision? Intellectual Property \& Technology Law Journal, 25(3), pp. 24-26.

Xenos, D. (2013) The European Unified Patent Court: Assessment and Implications of the Federalisation of the Patent System in Europe, SCRIPTed, Journal of Law, Technology \& Society, 10(2), pp. 246-277.

\section{About the author}

\section{Eugénio Lucas, PhD,}

is Associate Professor at Instituto Politécnico de Leiria, Instituto Jurídico Portucalense in Portugal. 
